\title{
Can Malaysia's National Affordable Housing Policy Guarantee Housing Affordability of Low-Income Households?
}

\author{
Jian Liu and Huay Ying Ong *
}

check for updates

Citation: Liu, J.; Ong, H.Y. Can Malaysia's National Affordable Housing Policy Guarantee Housing Affordability of Low-Income Households? Sustainability 2021, 13, 8841. https://doi.org/10.3390/ su13168841

Academic Editors: Grazia Napoli and Maria Rosa Trovato

Received: 18 May 2021

Accepted: 3 August 2021

Published: 7 August 2021

Publisher's Note: MDPI stays neutral with regard to jurisdictional claims in published maps and institutional affiliations.

Copyright: (c) 2021 by the authors. Licensee MDPI, Basel, Switzerland. This article is an open access article distributed under the terms and conditions of the Creative Commons Attribution (CC BY) license (https:// creativecommons.org/licenses/by/ $4.0 /)$.
School of Architecture, Tsinghua University, Haidian District, Beijing 100084, China; liujian@mail.tsinghua.edu.cn

* Correspondence: wenghy19@mails.tsinghua.edu.cn

\begin{abstract}
Housing affordability is a long-held issue in Malaysia, and housing policies have been implemented for low-income households over the years. However, there is a contradiction that housing affordability of low-income households has not been met, while the bulk of affordable housing is still vacant. In 2019, Malaysia enacted the National Affordable Housing Policy (DRMM) which was intended to improve housing affordability for low-income groups. This paper aims to answer why Malaysia's long-term implementation of affordable housing policies cannot guarantee housing affordability, and whether the DRMM can effectively improve housing affordability as expected, by comparing the empirical factors of housing affordability. A literature review and a comparative analysis are adopted in the research. The paper concludes that low household income, high land price, construction cost and compliance cost, mismatch of supply and demand in terms of quantity, the instability of the national economy, low home financing ability, and incomprehensive housing planning have caused low housing affordability of low-income groups in Malaysia. The $D R M M$ as anticipated can improve housing affordability by supplying affordable housing more precisely, lowering housing costs, and improving home financing ability. However, the exclusion of household income and economic factors may cause the ineffectiveness of the DRMM in improving housing affordability for low-income households.
\end{abstract}

Keywords: housing affordability; housing policy; affordable housing; Malaysia

\section{Introduction}

In 2019, Malaysia can be defined as a developing country comprised of 32.6 million people, 7.3 million households, and a total supply of 6.02 million homes, with its average household size decreasing to 3.9 persons from 4.1 persons in 2016 [1]. Shrinking household size, population growth, and urban migration have created an increasing demand for affordable housing. According to UN-Habitat [2], affordable housing is broadly defined as housing which is adequate in quality, location, and pricing that can sustain other basic living expenses. The term "affordable housing" is also often used to describe a housing unit that is affordable for those whose income is lower than the median household income in a place. The term "housing affordability" is often used to determine whether housing is affordable for households. There are three approaches commonly used to measure housing affordability, namely Median Multiple, Housing Cost Burden, and Residual Income [3]. In Malaysia, the Median Multiple method is used to evaluate the housing market and housing is considered affordable when the median price for the housing market is not more than three times the annual median household gross income [3-5]. Based on the 2019 Household Income and Basic Amenities survey [6], the Malaysian annual median household gross income was MYR 70,476; thus, affordable housing should have a market median price of MYR 211,428. As household income levels reveal a variance among states, the price of affordable housing is in two ranges; either less than MYR 150,000 or between MYR 150,001-MYR 300,000 [7]. In this paper, affordable housing refers to a housing with a selling price that does not exceed MYR 300,000. 
Over the years, long-term affordable housing policies for the low-income groups have been implemented in Malaysia. However, based on a report from Khazanah Research Institute [4], Malaysian housing affordability has not improved significantly between 2002 and 2016. Over this period, housing was considered "seriously unaffordable" with the median multiple varying between four and five. In 2019, the average price for a Malaysian home, as measured by the Malaysian House Price Index, was MYR 426,155, while the average per capita income was MYR 45,034. According to the research issued by The Edge Malaysia [1], within a timeframe of almost 30 years from 1990 to 2019, the average housing prices have increased 5.6 times while the real income measured by GDP per capita has only grown 2.8 times. It means that the growth in housing prices has surpassed real income by two times since 1990.

The National Property Information Centre (NAPIC) [8] showed that 30,664 units of new residential property were unsold in 2019, among which $32.4 \%$ was affordable housing. This reflects the contradiction that whilst the housing affordability of low-income households cannot be met, the bulk of affordable housing is still vacant. In 2019, Malaysia enacted the National Affordable Housing Policy (DRMM) which was intended to solve this contradiction and to improve the housing affordability for low-income groups to own a house. In such circumstances, this paper attempts to find the reasons why low-income households have low housing affordability and whether the DRMM can guarantee housing affordability of low-income groups.

Drawing on a series of studies that have been completed, there are few that have reviewed the evolution of Malaysia's affordable housing policy to deal with the issue of housing affordability. Shuid [9] divided the evolution of Malaysia housing provision system from 1971 to 2011 into four phases to analyse the key players in housing provision. Masram and Misnan [10] used the housing provision framework to analyse the key affordable housing policies of Malaysia. There are even fewer that have evaluated the effect of the long-term policy implementation to address housing affordability. International experiences have proved that housing affordability can be solved by increasing the quantity of affordable housing and lowering housing costs. Malaysia has implemented both strategies, but the housing affordability issue has never been solved. This real scenario is that whilst housing affordability of low-income groups is not achieved, the majority of affordable housing supplied for low-income households remains unsold. What caused this scenario to happen in Malaysia is an interesting question to ask and the answer to this question will be an academic contribution that can help to enhance the strategy to improve the housing affordability issue effectively. Moreover, up to now, no researcher has attempted to explore whether the DRMM could guarantee the housing affordability of low-income groups. This is the first study that draws attention to DRMM strategies in improving the housing affordability of low-income groups. The findings have important implications for the revising of the DRMM strategies to improve the housing affordability of low-income groups. The results will also influence future housing policies in Malaysia.

This paper begins with the definition of housing affordability and its influencing factors based on the international literature. Then, the paper subsequently reviews the evolution of Malaysia's affordable housing policy since its independence in 1957, analyses the reasons for the low housing affordability of low-income households in Malaysia and evaluates the effectiveness of the strategies proposed in the DRMM by comparing them with the influencing factors of housing affordability. Lastly, the paper concludes with a discussion on the results of analysis and evaluation, as well as the suggestions for revising the DRMM strategies and drafting future housing policies to improve the housing affordability of low-income groups.

\section{Housing Affordability and Its Influencing Factors}

Housing affordability is a global issue which many countries have attempted to overcome. It is not an inherent attribute of a housing unit, but rather a relationship between housing and people [11], depending on one's ability to pay for a housing unit. Housing 
affordability is often related to "affordable housing" for low-income groups, but it is a problem regardless of whether people are rich or poor. As mentioned earlier, the Median Multiple method is used to assess the Malaysian housing market. Based on the concept, in this paper housing affordability is defined as the ability of Malaysian low-income households (B40) to own a house, with the housing price-to-income ratio not exceeding three. Low-income households include poor households with a monthly income of less than the poverty line income (PLI). The analysis of housing affordability in this paper is limited to home buyers due to the insufficient data on rental housing.

A deep understanding of the influencing factors of housing affordability is crucial to determine the reasons for low housing affordability. The international literature indicates that housing affordability is generally affected by four dimensions, i.e., household income, housing price, home financing ability, and housing planning. However, there are many factors that impact housing prices [12]. According to Mostafa [13], housing prices vary along with the changes in regional economics. The development cost which consists of land cost, hard costs (construction costs), and soft costs (consultant fees and processing costs) can also alter housing prices [14]. Meanwhile, housing obtains its price due to the factors surrounding supply and demand, which can be proved in the cases of the US [15] and Australia [16]. In those countries, the disparity between housing supply and demand has led to either an increase or decrease in housing prices. Thus, the influencing factors of housing prices are interpreted in this paper in terms of land cost, construction cost, compliance cost, supply and demand, and economic factors. Based on international experience, the following eight factors are identified as the most significant in view of their influences on Malaysia's housing affordability.

\subsection{Household Income}

Low household income is recognised by many countries/regions as the key factor of the shelter-cost burden, such as in the UK [17], mainland China [18], Hong Kong China [13], Canada [12], Australia [19], Kenya [20], and Nigeria [21], which can significantly influence housing affordability from the perspective of housing accessibility and purchasing power [22]. Housing affordability suffers when housing prices go too much ahead of household income [15,23]. This can be further supported by Duan [18] who argued that household income impacts housing demand because it is a benchmark for one's purchasing power that could affect an individual's ability to obtain a mortgage loan.

\subsection{Land Cost}

Limited space and scarce land resources cause high land prices which are ultimately reflected in housing prices [24]. According to the New Straits Times [25] and the Daily Express [26], land scarcity is a key influential factor affecting the increase in housing prices, especially in the urban areas of big cities such as Kuala Lumpur. Meanwhile, the increase in land prices is a major factor that influences housing affordability. The conversion of land into residential use incurs a land cost [23], which consequently burdens home buyers. That is the reason why the UN-HABITAT [2] outlines the total land cost as one of the factors affecting housing affordability.

\subsection{Construction Cost}

Construction costs, such as infrastructure, building materials, and labour are also known as hard costs in total housing development costs. A household's ability to purchase a home becomes worse when the construction costs and housing prices become higher $[2,14,16,19,26]$.

\subsection{Compliance Cost}

Compliance cost is incurred from the payment of land conversion, processing fees, and statutory contribution charges to utility companies. When compliance costs from local regulations are involved, housing development becomes riskier, longer, and more 
expensive, which in turn impacts housing affordability [27]. For example, in the U.S., the Dept. of HUD uses the compliance cost that is associated with effluent regulation to measure the change in housing affordability [28].

\subsection{Relation between Supply and Demand in Terms of Quantity}

It is widely believed that housing affordability can reflect housing market conditions [29,30]. The housing affordability issue may become urgent as the demand for affordable housing continues unabated and can be further intensified by an inadequate supply of affordable housing [16,24]. The failure of housing supply to meet with a proportionate demand along with population growth may raise the pressure on housing prices and housing affordability [15]. According to Yap and $\mathrm{Ng}$ [23], the residential real estate market in high population density cities is always active with routine transactions, thus housing prices are increased, which influences housing affordability.

\subsection{Situation of National Economy}

Economic changes could impact construction costs and inflate housing prices, as housing prices depend on the economic conditions including either inflation or deflation [31]. In the case study of Hong Kong, a regression analysis over time was taken to evaluate the impact of economic factors on the housing affordability of low-income households in terms of GDP, the inflation rate, and the unemployment rate [13]. The result showed that economic growth did not significantly affect the housing affordability of low-income groups while inflation and unemployment rates negatively did. Worthington and Higgs (2013) also found that economic growth is a short-term issue for housing affordability while the taxation imposed on housing will affect housing affordability in the long run.

\subsection{Capability of Home Financing}

A good financial plan is needed for home buyers to achieve long-term affordable homeownership. Finance for housing is a fundamental factor used in determining housing affordability [16,32] which is represented by two financing abilities, i.e., the ability of financing for purchase through a down payment and the ability of a financial service to pay the housing loan and interest rates after cutting non-housing expenditure [2]. A tight lending environment further exacerbates the issue of securing home financing from private banks [23]. In general, saving capacity [19,29], household expenditure [21,33], and monthly instalments $[20,33,34]$ are the basic financial costs that influence housing affordability.

\subsection{Housing Planning Justified by Data Analysis}

International experience has showed that a scientific and reasonable housing plan based on housing market analysis is essential for affordable housing delivery and housing affordability [16]. Insufficient analysis on household data in housing plans often causes an inaccurate estimation of market demand and discrepancy in views between households and developers. Consequently, product mismatch [4] will appear which may lead to the rise of vacant affordable houses that cannot meet expectations and cannot benefit the people [34]. In other words, many people would not find suitable and affordable housing where developers fail to provide the right types of properties at the right location [35].

\section{Policy Initiatives of Malaysia's Affordable Housing Development}

In Malaysia, before the National Housing Policy was issued in 2012, housing policy evolved through the country's five-year development plans. Low-cost housing was considered as affordable housing when it was subsidised and was allocated only to low-income people with several eligibilities set by the government [36]. This section reviews the evolution of Malaysia's affordable housing policy from 1957 in chronological order. Table 1 shows the government's initiatives of affordable housing development with different policies in different periods. 
Table 1. Policy initiatives of Malaysian government in affordable housing development since 1957.

\begin{tabular}{|c|c|c|c|c|}
\hline \multirow{2}{*}{ Phase } & \multirow{2}{*}{ Backgrounds and Challenges } & \multicolumn{2}{|c|}{ Initiatives of Government } & \multirow{2}{*}{ Implementation Effects } \\
\hline & & Name of Policy & Strategies & \\
\hline \multirow[t]{2}{*}{ 1957-1970 } & \multirow[t]{2}{*}{$\begin{array}{l}\text { Rural-urban migration, } \\
\text { squatter and overcrowding } \\
\text { problems }\end{array}$} & $\begin{array}{l}\text { First Development Plan for } \\
\text { Malaya and Secondary } \\
\text { Five-Year Plan (1956-1965) }\end{array}$ & $\begin{array}{ll}- & \text { Improve basic } \\
\text { infrastructure and rural } \\
\text { development }\end{array}$ & $\begin{array}{ll}\text { - } & \text { 23,236 government } \\
\text { quarters and } 8938 \text { low-cost } \\
\text { housings constructed } \\
\text { Shortage of low-cost } \\
\text { housing }\end{array}$ \\
\hline & & $\begin{array}{l}\text { First Malaysia Plan } \\
(1966-1970)\end{array}$ & $\begin{array}{ll}- & \text { Housing Crash } \\
\text { - } & \text { Programme } \\
& \text { Laws enacted for } \\
\text { squatter clearance }\end{array}$ & $\begin{array}{l}21,790 \text { low-cost housing } \\
\text { constructed, } 73 \% \text { of the } \\
\text { target }\end{array}$ \\
\hline \multirow[t]{3}{*}{ 1971-1985 } & \multirow[t]{3}{*}{$\begin{array}{l}\text { Tragedy of 13th May 1969, New } \\
\text { Economic Policy (NEP) was } \\
\text { established }\end{array}$} & $\begin{array}{l}\text { Second Malaysian Plan } \\
\text { (1971-1975) }\end{array}$ & $\begin{array}{ll}\text { - } & \text { Housing programs } \\
\text { carried out in line with } \\
\text { NEP objectives } \\
\text { - } \quad \text { Low-cost housing built } \\
\text { by state governments } \\
\text { with subsidised Federal } \\
\text { loans } \\
\text { - Core Housing concept }\end{array}$ & $\begin{array}{l}13,244 \text { units completed, } \\
50.5 \% \text { of the target }\end{array}$ \\
\hline & & $\begin{array}{l}\text { Third Malaysian Plan } \\
(1976-1980)\end{array}$ & $\begin{array}{ll}- & \text { Control on housing } \\
\text { costs } \\
-\quad & \text { Provision of funds } \\
- & \text { Housing loan } \\
\text { repayment period } \\
\text { extended from } 20 \text { years } \\
\text { to 25 years }\end{array}$ & $\begin{array}{l}26,000 \text { units completed, } \\
35 \% \text { of the target }\end{array}$ \\
\hline & & $\begin{array}{l}\text { Fourth Malaysian Plan } \\
\text { (1981-1985) }\end{array}$ & $\begin{array}{l}\text { Low-cost Housing } \\
\text { concept } \\
30-50 \% \text { of private } \\
\text { housing projects for } \\
\text { low-cost housing at } \\
\text { maximum MYR 25,000 } \\
\text { per unit }\end{array}$ & $\begin{array}{l}\text { Public sector: } 71,310 \text { units } \\
\text { completed, } 40.4 \% \text { of the } \\
\text { target } \\
\text { Private sector: } 19,170 \text { units } \\
\text { completed, } 21.9 \% \text { of the } \\
\text { target }\end{array}$ \\
\hline \multirow[t]{2}{*}{ 1986-1997 } & $\begin{array}{l}\text { Economy depression from } 1986 \\
\text { to } 1987\end{array}$ & $\begin{array}{l}\text { Fifth Malaysia Plan } \\
\text { (1986-1990) }\end{array}$ & $\begin{array}{ll}- & \text { Promote open market } \\
\text { policy } \\
\text { - } & \text { Reduction in public } \\
\text { housing development } \\
\text { budget } \\
\text { - } \quad \text { Establishment of one } \\
\text { stop agency } \\
\text { - } \quad \text { Establishment of } \\
\text { Recovery Fund for } \\
\text { Abandoned Housing } \\
\text { Project in } 1990\end{array}$ & $\begin{array}{l}\text { Private sector: } 88,880 \text { units } \\
\text { completed, } 24 \% \text { of the } \\
\text { target } \\
\text { Public sector: } 74,330 \text { units } \\
\text { completed, } 61 \% \text { of the } \\
\text { target } \\
\text { Housing Scheme: Special } \\
\text { low-cost Housing } \\
\text { Program }\end{array}$ \\
\hline & $\begin{array}{l}\text { To provide adequate housing } \\
\text { and ensure houses built are } \\
\text { accessible and affordable for all } \\
\text { citizens, especially low } \\
\text { income group }\end{array}$ & $\begin{array}{l}\text { Sixth Malaysia Plan } \\
\text { (1991-1995) }\end{array}$ & $\begin{array}{ll}- & \begin{array}{l}\text { Implementation of the } \\
\text { concept of Human }\end{array} \\
\text { Settlement } \\
\text { Implementation of } \\
\text { cross-subsidies method } \\
\text { - } \quad \text { Establishment of } \\
\text { Low-cost Housing Fund } \\
\text { in 1993, Housing } \\
\text { Foundation for the } \\
\text { Poorest People, and } \\
\text { Low-cost Housing } \\
\text { Revolving Fund in } 1994\end{array}$ & $\begin{array}{l}\text { Private sector: } 214,889 \\
\text { units completed, } 98.9 \% \text { of } \\
\text { the target } \\
\text { Public sector: } 46,497 \text { units } \\
\text { completed, } 36.7 \% \text { of the } \\
\text { target as inapt project } \\
\text { sites, and high } \\
\text { construction costs } \\
\text { Housing Scheme: Special } \\
\text { Low-cost Housing } \\
\text { Program }\end{array}$ \\
\hline
\end{tabular}


Table 1. Cont.

\begin{tabular}{|c|c|c|c|c|}
\hline \multirow{2}{*}{ Phase } & \multirow{2}{*}{ Backgrounds and Challenges } & \multicolumn{2}{|c|}{ Initiatives of Government } & \multirow{2}{*}{ Implementation Effects } \\
\hline & & Name of Policy & Strategies & \\
\hline \multirow[t]{3}{*}{ 1998-2010 } & $\begin{array}{l}\text { Asian Financial Crisis from } \\
1997 \text { to 1998, economy } \\
\text { breakdown, squatter problem } \\
\text { was rising in 1990s }\end{array}$ & $\begin{array}{l}\text { Seventh Malaysia Plan } \\
\text { (1996-2000) }\end{array}$ & 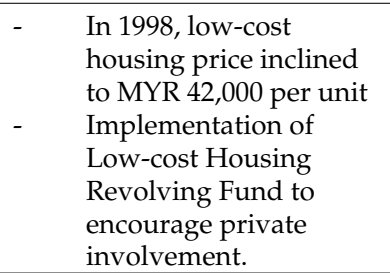 & $\begin{array}{ll}\text { - } & \text { 190,597 units completed, } \\
\text { 95.3\% of the target } \\
\text { - } \quad \text { Housing Scheme: } \\
\text { - } \quad \text { Integrated People's } \\
\text { Housing Program (SPNB), } \\
1998\end{array}$ \\
\hline & & $\begin{array}{l}\text { Eighth Malaysia Plan } \\
\text { (2001-2005) }\end{array}$ & 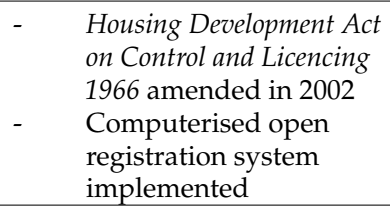 & $\begin{array}{l}\text { 210,529 units completed, } \\
\text { 85\% of the target } \\
\text { Housing Scheme: Program } \\
\text { Perumahan Mampu Milik; } \\
\text { Program Perumahan Mesra } \\
\text { Rakyat } \\
\end{array}$ \\
\hline & & $\begin{array}{l}\text { Ninth Malaysia Plan } \\
(2006-2010)\end{array}$ & $\begin{array}{l}\text { Provision of adequate, } \\
\text { affordable, and quality } \\
\text { houses, with greater } \\
\text { emphasis on } \\
\text { appropriate locations } \\
\text { and conducive living } \\
\text { environment }\end{array}$ & $\begin{array}{l}\text { - } 95,800 \text { units completed, } \\
91.2 \% \text { of the target } \\
\text { Housing scheme: Program } \\
\text { Perumahan Rakyat; Program } \\
\text { Perumahan Mesra Rakyat }\end{array}$ \\
\hline 2011-2015 & $\begin{array}{l}\text { In 2010, National Transformation } \\
\text { Policy was introduced to } \\
\text { achieve the Government } \\
\text { Transformation Programme. }\end{array}$ & $\begin{array}{l}\text { Tenth Malaysia Plan } \\
\text { (2011-2015); } \\
\text { National Housing Policy, } \\
2012\end{array}$ & 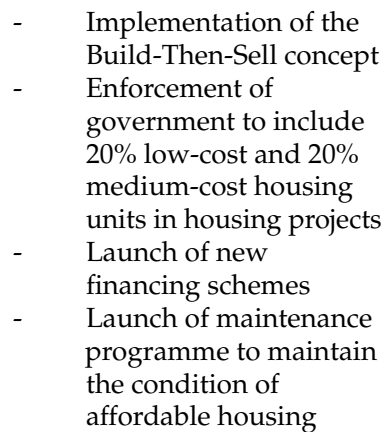 & $\begin{array}{l}\text { - } 102,201 \text { units completed or } \\
56.3 \% \text { of the target } \\
\text { - Various housing schemes } \\
\text { introduced for both low- } \\
\text { and middle-income } \\
\text { households }\end{array}$ \\
\hline 2016-now & $\begin{array}{l}\text { Unsold property in Malaysia } \\
\text { due to mismatch of supply and } \\
\text { demand and unaffordable } \\
\text { housing price for the target } \\
\text { group }\end{array}$ & $\begin{array}{l}\text { Eleventh Malaysia Plan } \\
\text { (2016-2020); National } \\
\text { Housing Policy (2018-2025); } \\
\text { National Affordable Housing } \\
\text { Policy, } 2019\end{array}$ & 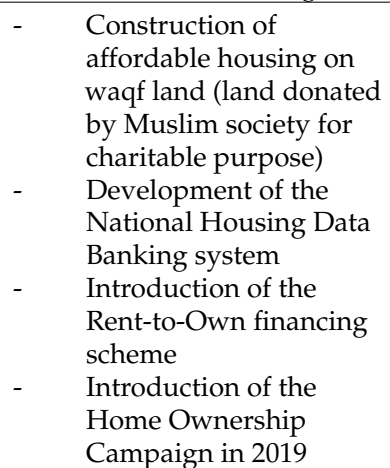 & $\begin{array}{l}\text { From } 2016 \text { to } 2017,139,329 \\
\text { units completed or } 30.9 \% \\
\text { of the target } \\
\text { Various affordable } \\
\text { housing programs } \\
\text { launched for those low- } \\
\text { and middle-income } \\
\text { households }\end{array}$ \\
\hline
\end{tabular}

Source: Tabulated by the authors according to relative documents [37-54].

\subsection{Low-Cost Housing Development after Independence: 1957-1970}

After Malaysia gained its independence in 1957, the government started looking into squatter and overcrowding problems within housing developments caused by rural-urban migration. A small amount of the national budget was allocated for low-cost housing development under the First Development Plan for Malaysia and the Second Five Year Plan (1956-1965). Housing development was not the priority of the government but housing provision for civil servants was [36]. This resulted in the construction of 23,236 government quarters and 8938 low-cost homes for civil employees and low-income groups, respectively, by the government [37].

From 1966 to 1970, squatter and slum problems gained more attention. According to Yusoff [37], laws were enacted for squatter clearance, such as The Emergency (Essential 
Powers) Clearance of Squatters Regulation (Laws of Malaysia 1969), Kuala Lumpur Federal Capital (Clearance of Squatters) Bylaw (Kuala Lumpur City Hall 1963), and Section 425 of the National Land Code (Laws of Malaysia 1965). The First Malaysia Plan (1966-1970) stated the goal of improving the well-being of low-income groups, making the construction of lowcost housing a milestone in achieving the goal. In 1967, the "Housing Crash Programme" was implemented as the initiative of government to provide low-cost housing and 32 to 50 low-cost houses were constructed in the areas without low-cost housing [38]. During this period, a total of 21,790 units were constructed, meeting $73 \%$ of the target, as one of the great endeavours of the government in promoting the well-being of low-income groups.

\subsection{Housing the Poor: $1971-1985$}

After the race riots tragedy of 13 May 1969 due to income and social inequality, the New Economic Policy (NEP) was launched in 1971 to address the socio-economic gaps. Many housing programs were carried out to achieve one of the NEP's objectives [39], i.e., to reduce and to eradicate poverty in Bumiputera (Malays and indigenous people of Malaysia). The quota system was introduced in housing development to make it mandatory for developers to include $30 \%$ of low-cost housing in most residential projects [40]. The "Core Housing" concept was unveiled under the Second Malaysia Plan (1971-1975) which was designed to provide low-income groups with very basic accommodation, allowing them to expand and improve their housing according to their economic conditions [37]. In the Third Malaysia Plan (1976-1980), several initiatives were implemented to control the housing cost, such as increasing the building density, decreasing the unit floor-area, reducing the front porch, and lowering the infrastructure facility standard. To accelerate low-cost housing construction, the government provided funding and extended the loan repayment period from 20 to 25 years for developers [41]. During the Fourth Malaysia Plan (1981-1985), the "Low-Cost Housing" concept was implemented which stressed the production of low-cost housing in urban areas [36]. In 1981, the government enforced that $30-50 \%$ of private housing projects should be low-cost housing with a maximum cost of MYR 25,000 per unit, forcing the involvement of the private sector in low-cost housing development [39]. Since then, low-cost housing development has been one of the goals in every five-year national development plan.

In terms of performance, the low-cost housing development increased from 1971 to 1985. Under the Second Malaysia Plan (1971-1975), 13,244 units were completed, achieving $50.5 \%$ of the target. Housing rose to 26,000 units under the Third Malaysia Plan (1976-1980). However, it only achieved $35 \%$ of the target due to the reduced role and the lack of manpower of the reshuffled housing ministry [42]. Under the Fourth Malaysia Plan (1981-1985), the public and private sectors contributed 71,310 (40.4\% of the target) and 19,170 (21.9\% of the target) low-cost houses, respectively [37].

\subsection{Housing Market Reform: 1986-1997}

From 1986 to 1987, Malaysia's economy was in recession due to the global financial crisis, resulting in a reduction in the government's budget for housing development in the Fifth Malaysia Plan (1986-1990) and the Sixth Malaysia Plan (1991-1995). The housing policy then was stipulated in line with the goal of international institutions, such as the World Bank and the International Monetary Fund, to promote an open market and to reduce government involvement in business affairs [39]. Under the Fifth Malaysia Plan, the institution of the One Stop Agency was established to facilitate the approval of housing project applications and to help developers obtain bank loans, and the Recovery Fund for Abandoned Housing Project was initiated to help developers complete their abandoned projects. Under the Sixth Malaysia Plan, while the concept of "Human Settlement" was implemented in housing schemes to take into consideration the need for social facilities, housing types, and financial accessibility for low-income groups [36], the cross-subsidies method was implemented to allow developers to cover the loss from low-cost housing 
with a gain from ordinary housing by charging higher prices. Funding was established to speed up the provision of low-cost housing.

During this period, the total low-cost housing production increased to hundreds of thousands of homes, with the majority being supplied by the private sector. Under the Fifth Malaysia Plan, the private and the public sectors completed 88,880 (24\% of the target) and 74,330 units ( $61 \%$ of the target) of low-cost housing, respectively [43]. Under the Sixth Malaysia Plan, the low-cost housing production reached its peak of 261,386 units, with $82.2 \%$, i.e., 214,889 units from the private sector and 46,497 units from the public sector [44].

\subsection{Slum Clearance: $1998-2011$}

In the Asian Financial Crisis of 1998, the challenges of economic turmoil urged the Malaysian government to establish the Economic Action Council to improve economic growth and to address the squatter problem. In 1998, the Malaysian government launched a special low-cost housing program, i.e., the Integrated People's Housing Program, to relocate the squatters in urban areas, especially those in Kuala Lumpur, by raising the maximum low-cost housing price from MYR 25,000 to MYR 42,000 per unit in view of the non-profitability caused by high land, infrastructure, and development costs in CBD areas [39]. By allowing developers to gain more competitive profits, this readjustment showed the government's initiative in encouraging the greater involvement of both public and private developers in low-cost housing development. In 2002, the Housing Development Act on Control and Licencing 1966 was amended to improve the effectiveness of housing development [45]. At the same time, the Computerised Open Registration System was implemented as part of the screening process of eligible buyers.

In terms of policy performance, under the Seventh Malaysia Plan (1996-2000), 95.3\% of the target of 190,597 units was achieved, among which the private sector contributed 129,598 units [46]. Under the Eighth Malaysia Plan (2001-2005), the public sector completed 113,235 units and achieved $54.4 \%$ of the target, while the private sector completed 97,294 units and achieved more than double the target, respectively. During the period of the Ninth Malaysia Plan (2006-2010), housing development continued to focus on the provision of adequate, affordable, and quality houses for all Malaysians, with a greater emphasis on appropriate locations and conducive living environments [47]. As the housing market was led by the private sector and supported by the public sector, the private sector contributed more in high-cost housing, with its contribution to low-cost housing gradually decreasing.

\subsection{First Affordable Housing Initiative: 2011-2015}

The National Transformation Policy was introduced in 2010. Under the Government Transformation Programme, seven National Key Results Areas were identified as being in urgent need for drastic actions from the government. Among them, two areas, i.e., "raising living standard of low-income households" and "improving rural basic infrastructure", were correlated to housing development. Over the years the housing policies stated in the Malaysia plans had emphasised the objective of delivering affordable and sufficient housing to low-income groups and the growing number of the middle-income segment had also led to the increasing demand for affordable housing. In 2012, the National Housing Policy was issued, which became the direction for all relevant parties involved in housing development. It stated six thrusts and twenty policy directions to provide sufficient housing for low- and middle-income groups. In 2013, the government set up the target of building 1.1 million affordable homes in five years to meet the market demand [48] and stated that housing projects should include $20 \%$ low-cost and $20 \%$ medium-cost housing units in 2014 [49]. In the same period, the Build-Then-Sell concept was implemented, apart from the One Stop Centre system established in 2007, to shorten the approval process.

During this period, both the public and the private sectors, as well as the joint ventures between them, offered affordable housing to increase the accessibility of owning or renting a house. A total of 102,201 affordable houses were completed under the Tenth Malaysia 
Plan (2011-2015) within the framework of various programmes designed to fulfil the needs of different target groups, such as Program Bantuan Rumah, Program Perumahan Rakyat, Rumah Mesra Rakyat 1Malaysia, and the Rent-to-Own Programme for low-income households, and the Perumahan Rakyat 1 Malaysia (PR1MA), 1Malaysia Civil Servants Housing (PPA1M) and Rumah Wilayah Persekutuan (RUMAWIP) for middle-income households. New financing schemes were offered, such as the My First Home Scheme, the Youth Housing Scheme, and the Private Affordable Ownership Housing Scheme (My Home), to provide financial assistance to home buyers. To maintain the condition of affordable housing, the government also implemented the Housing Maintenance Program, the 1Malaysia Maintenance Fund, and the My Beautiful Malaysia programme for public low-cost housing, private low- and medium-cost housing, and government quarters, respectively [50].

\subsection{Continued Affordable Housing Development: 2016 Till Now}

In 2017, the Central Bank of Malaysia declared that residential property in Malaysia had reached its peak in a decade but nearly half of the total PR1MA homes (25,132 units) were unsold as recorded on 15 November 2017, showing the mismatch between supply and demand by price [51]. The provision of PRIMA homes was priced from MYR 100,000 to MYR 400,000, where housing priced above MYR 250,000 was considered unaffordable for the target groups. Based on the Housing Cost Burden approach, the National Bank estimated in 2016 that the maximum affordable housing price should be MYR 282,000. However, the actual median housing price was MYR 313,000 [52].

In 2018, the National Housing Policy (2018-2025) was enacted to provide adequate and affordable housing for the needy. As a sub-policy, the National Affordable Housing Policy, i.e., the DRMM, was issued in 2019 to further address the problems of affordable housing for low- and middle-income households. Both policies outlined a set of guidelines for all parties involved in affordable housing delivery, such as the determination of price range for each state and the establishment of housing standards to be fulfilled by developers. They also described the government's initiatives in reducing affordable housing costs in terms of land price, development charge, and compliance cost, developing an integrated housing system and setting up a platform of education and advice on financial matters.

The DRMM created a unified policy framework for developers to build affordable and cost-saving housing for the target groups of low- and middle-income households. As a result, 458 public affordable housing projects were constructed on the waqf land through the cooperation between the Department of Waqf, Zakat dan Haj (JAWHAR), and other institutions, such as state Islamic religious councils, state governments, and local authorities. The National Housing Department developed the National Housing Data Banking System as an integrated housing information system that allowed data sharing among agencies and state governments to facilitate the coordination to determine the suitable locations of affordable housing [39]. Several financing initiatives were also provided to improve the housing affordability of low- and middle-income households, such as the Rent-to-Own financing scheme. In 2019, the Home Ownership Campaign was launched to promote Malaysian homeownership and to overcome the issue of unsold properties [53]. By the mid-term of the Eleventh Malaysia Plan (2016-2020), 139,329 units and $30.9 \%$ of the target had been completed for low- and middle-income households [50], while the homeownership of low- and middle-income households was increased through various affordable housing programs. However, there was still a shortage of affordable housing in urban areas.

\section{Why Do Low-Income Households Have Low Housing Affordability in Malaysia}

The previous policy review shows that whilst Malaysia has made long-term efforts to overcome the housing affordability issue by implementing a series of affordable housing policies, housing affordability in Malaysia is still at low levels. To find out the reasons 
for that paradox, the current housing affordability condition of low-income groups was analysed by comparing them with the eight identified influencing factors.

\subsection{Low Household Income}

Based on the Household Income and Basic Amenities survey in 2019 [6], the average Malaysian earns MYR 5873 per month with an annual median household income of MYR 70,476. Hence, an affordable housing price should not exceed MYR 211,428 based on three times the median multiple. However, the median housing price at MYR 426,155 makes residential houses seriously unaffordable for many Malaysians [1]. The 2019 Household Income and Basic Amenities survey showed that low-income groups (16\% of Malaysia's households) were earning MYR 3166 and below and that half of the total households in Malaysia were not earning more than the median household income of MYR 5873 [6]. Data from the Employees Provident Fund (EPF) showed that $89 \%$ of Malaysian employees had a monthly salary of less than MYR 5000 and the majority of low-income households barely had enough funds after their retirements [54]. It means that the low household income makes the majority of Malaysians unable to afford and own a house.

\subsection{High Land Cost}

In Malaysia, the cost of land accounts for $20 \%$ of the total housing development costs and is considered as one of the largest proportions of property development expenses [14]. Therefore, the high land cost is critical to the viability of affordable housing for all Malaysians.

\subsection{High Construction Cost}

In Malaysia, the costs for infrastructure, building materials, and labour potentially influence housing affordability when the economy changes [23,24]. Many developers face challenges of skilled worker shortages on construction projects. According to Ramli et al. [55], $80 \%$ of the Malaysian governments' projects fall behind schedule as a consequence of poorly qualified contracted technical staff. Delays in construction projects then exert extra pressure on total construction costs. In consequence, developers launch higher housing prices after considering all the construction costs to boost profit margins.

\subsection{High Compliance Cost}

In Malaysia, high compliance costs from various governmental regulations, such as title application, land conversion, and project approval further increase housing prices, leading to low housing affordability $[23,26]$. Three factors contribute to the high compliance cost, i.e., the inefficiency of the housing delivery process and system, the corrupt bureaucrats, and the distinction of power that discourages cooperation between federal and state governments [24]. The development approval process consists of various permits that involves many government agencies from both federal and local levels which have different bureaucratic processes, which often leads to developers choosing to undertake unnecessary transactions to speed up the approval process. This may acquire extra processing charges and can increase the developer's final selling price. Based on the Real Estate and Housing Developers' Association of Malaysia (REHDA) survey, compliance costs can range from $2.8 \%$ to $19.9 \%$ of the Gross Development Value (GDV) for high-rise developments. It can range from $9.5 \%$ to $35.1 \%$ of the GDV for land development [56]. These costs are inevitably and ultimately reflected in the increase in housing prices.

\subsection{Mismatch between Supply and Demand in Terms of Quantity}

In Malaysia, the construction of affordable housing has fallen behind the target provision for years, which means that the supply of affordable housing can only partially respond to the cyclical changes in demand. Yet, the demand for affordable housing from low-income households continues to grow due to high population density and rapid popu- 
lation growth. An insufficient housing supply ultimately leads to an increase in housing prices, consequently affecting housing affordability.

\subsection{Instability of National Economy}

Indeed, in Malaysia, economic growth does not help improve affordability, while the affordability is affected by the unstable economy in terms of a weak currency, the depreciated value of the Malaysian Ringgit, and inflation [23]. So far, taxation is not an issue for Malaysian housing affordability as there is a property tax exemption for low-cost housing and affordable housing as well [57].

\subsection{Low Capability of Home Financing}

In Malaysia, housing loans are becoming more difficult to obtain while the loan approval process is getting longer. Housing loans with high interest rates imposed by banks cause high monthly installments, making housing units pricey and unaffordable for households $[15,18]$. Besides monthly instalments, households have to pay for monthly maintenance fees, causing further financial burdens for already low-income households [58].

\subsection{Incomprehensive Housing Planning Due to Information Insufficiency}

In 2013/2014, Malaysia experienced a high rise in housing prices. Locations and sizes were also mismatched with the market demand due to the insufficient analysis on household data. Inaccurate data contributed to false perceptions by developers on market demand that consequently resulted in vacant housing and impacted housing affordability [59]. The National Housing Policy is not well implemented due to a faulty market analysis and insufficient information. Hence, the long-term implementation of housing plans has not significantly improved Malaysian housing affordability as expected.

\section{Can the DRMM Guarantee Housing Affordability of Low-Income Households}

As a sub-policy prepared by the MHLG through the National Housing Department, the DRMM aims to overcome five identified challenges of affordable housing development in Malaysia more comprehensively, i.e., unaffordable housing price; imbalanced housing supply and demand; housing product mismatch; insufficient coordination; and failure of financial support, with regard to which six objectives are targeted including ensuring housing affordability. To achieve the objectives, a number of strategies are prescribed in accordance with the criteria of affordable housing and government's initiatives. The following discusses the results of the evaluation of the DRMM strategies to overcome housing affordability with reference to the eight influential factors affecting Malaysia's housing affordability analyzed in the previous section.

\subsection{Strategy 1: Centralise Affordable Housing Authority}

According to the DRMM, the Malaysian government aims to build one million affordable homes for low-income households within 10 years, commencing in 2019, to raise their homeownership [60]. However, it is quite challenging because there are more than 20 agencies at both federal and state levels that are involved in affordable housing development. They are neither integrated nor coordinated, and due to that, the housing that is supplied often does not match well with the actual demand. Thus, the DRMM strategy for centralised housing authority is mandated to improve housing affordability. To coordinate the fragmented federal and state governments' agencies, the Malaysian government has empowered the MHLG to act as the central housing agency and authority that coordinates all affordable housing projects. It is hoped that, by centralising the housing agencies and authorities, more comprehensive housing planning and urban development frameworks will be set up to strengthen the effectiveness of housing policies. 


\subsection{Strategy 2: Create a Unified Housing Database}

Currently, Malaysia does not have a unified database on the housing market that provides necessary information on households. The information insufficiency makes it difficult to supply housing effectively to meet the actual demand, resulting in many unsold residential properties, including affordable housing. The data issued by the National Property Information Centre in 2020 showed that the sum of unsold units in Malaysia increased almost three times over a five-year period, from 10,897 units in 2015 to 30,664 units in 2019 [34]. Regarding this matter, the DRMM mandates that an integrated housing database is developed that is beneficial for future affordable housing planning. The database will gather household data including economic status, family composition, and housing preferences through nationwide housing surveys. This will enable governments and developers to make more accurate estimations on the shortage of affordable housing and allocate affordable housing more precisely by identifying the potential and eligible buyers. Of course, the cooperation of all parties is needed in developing this integrated housing database.

\subsection{Strategy 3: Strengthen Development Control}

Development control is an integral part of planning practice and is essential to manage and regulate property development. Good development control can boost the effectiveness of housing provision, can help reach market equilibrium, and can eventually overcome the housing affordability issue [61]. In Malaysia, the administration of development control is within the exclusive power of the State Government and is subject to the consideration of the State Government Council. Therefore, the guidelines of the DRMM prescribe that the State Government Council is responsible for making comprehensive reviews on property market, conducting demand and supply studies, and providing strong justifications if there are any exceptions to the conditions such as changes in the percentage of affordable housing provision, conversion, and the relocation of land. Developers are subjected to penalties if they do not obey the government plans in delivering affordable housing. A quota system is stipulated to encourage the balance of housing development and to increase the supply of affordable housing, i.e., at least $30 \%$ of the total development project must be affordable housing and no less than $30 \%$ of affordable housing must be allocated to bumiputera. Each state government determines the quota based on the States' Guidelines on Bumiputera Quotas from Real Estate and Housing Developers' Association of Malaysia Institute (REHDA).

\subsection{Strategy 4: Control Affordable Housing Price}

As mentioned earlier, it is common sense that high housing prices are affecting Malaysia's housing affordability, especially for low-income groups. An adjustment of the housing price through the Median Multiple approach is required to ensure housing supply and to meet the market demand in terms of quantity, as well as to improve Malaysian housing affordability. Based on the median multiple measurement, the DRMM fixes the affordable housing prices for urban and rural areas in each state by determining the median household income from the Investigation Report of Household Income and Basic Facilities in 2016. Specifically, Kuala Lumpur will have the highest affordable housing price of MYR 326,628, followed by Putrajaya (MYR 297,900), and Selangor (MYR 267,948). By taking the average median household income of these three states (MYR 8191), the maximum affordable housing price is fixed at MYR 300,000. For the states that are less developed, such as Kelantan, Kedah, Perlis, and Perak, the maximum affordable housing price is fixed at MYR 150,000. In short, the DRMM fixes the affordable housing prices in two categories, i.e., below MYR 150,000 and between maximum MYR 300,000. Both price categories are considered affordable. Developers are mandated to provide affordable housing within the price range, so as to prevent them from adjusting housing profit margins as they wish. 


\subsection{Strategy 5: Prepare Land for Affordable Housing}

Continuous urbanization has increased housing demand in Malaysian cities, leading to an increase in housing prices and an effect on housing affordability. High land price is one of the factors increasing housing prices. In Malaysia, the land price usually depends on housing demand and market price. To reduce housing prices, the government plans to develop affordable housing on government lands. The MHLG and State Governments play a vital role in land preparation. In view of the expensive land price and scarcity of land in Malaysia, particularly in its urban areas, the DRMM highlights their role in preparing land for affordable housing as follows:

1. The DRMM encourages state governments to cooperate with the private sector for affordable housing developments;

2. The DRMM suggests state governments propose suitable lands for affordable housing development before submitting the project to the MHLG;

3. The DRMM mandates the formation by the MHLG of an Affordable Housing Implementation Evaluation Committee to evaluate the effectiveness of the construction methods and the costs of affordable housing for the government;

4. The DRMM mandates that the MHLG is authorised by the federal government through the Federal Land Commission to be responsible for planning, coordinating, and developing affordable housing.

Therefore, by offering affordable housing land for free or for nominal fees, the government can reduce the land price in the housing market and improve housing affordability.

\subsection{Strategy 6: Reduce Construction Cost}

Generally, construction cost accounts for the majority of new housing price in Malaysia. To improve the efficiency and effectiveness of delivering affordable housing projects and to reduce the construction cost while assuring construction safety, the DRMM mandates developers to adopt the Industrialised Building System (IBS) and encourages them to use Building Information Modelling (BIM) technology in affordable housing construction. The government also provides incentives and tax exemption on machines and tools for affordable housing construction to support the implementation of IBS. Obviously, the reduction in construction cost can help to reduce housing prices and then improve housing affordability.

\subsection{Strategy 7: Reduce Compliance Cost}

A high compliance cost is a burden on developers in Malaysian housing projects that impacts housing price and housing affordability. The DRMM promotes the state and local governments to reduce or exclude development and compliance costs. For instance:

1. Impose lower development charges;

2. Accelerate the approval process and provide a density bonus for affordable housing projects;

3. Impose lower land premiums (extension of leasehold, land alienation, and amalgamation) and land use conversion costs;

4. Exclude/reduce compliance costs imposed by the state and local governments on affordable housing projects.

With the exception and reduction in compliance costs, housing prices will decrease, and the government can supply more affordable housing, particularly in urban areas and strategic locations.

\subsection{Strategy 8: Ensure Appropriate Dwelling Conditions}

Inaccurate information delivered by the government meant that developers failed to construct suitable housing types and sizes, which led to the mismatch between market demand and supply of liveable affordable housing. Therefore, it is necessary for the government to include the criteria of appropriate dwelling conditions for affordable housing in the housing policy. The DRMM specifies several criteria as the guidelines for all parties 
involved in affordable housing projects to deliver affordable housing with conducive and appropriate dwelling conditions, such as building design, unit floor area, housing density, and facilities. These criteria of appropriate dwelling conditions are expected to make affordable housing projects more adaptable to household expectations and market demands.

\subsection{Strategy 9: Improve Household Financial Literacy}

Financial literacy is vital to avoid household debt. According to the Central Bank of Malaysia's Financial Capability and Inclusion Demand Side Survey 2018, one in three Malaysians deems that they have little financial knowledge, especially those in low-income households [62]. Poor financial management generally stems from a lack of financial knowledge and the capability to make good financial decisions, weakening their housing affordability when they come across a home that they can potentially purchase. Therefore, the DRMM mandates the Central Bank of Malaysia and its management agency AKPK to establish the Credit Counselling system to educate and advice the public on financial matters. This will improve an individual's financing ability and assist them in their home purchasing journey and ensure housing affordability.

\subsection{Strategy 10: Launch Various Housing Financing Schemes}

The DRMM encourages the government to launch various housing financing schemes for low- and middle-income groups in order to raise their homeownership. For instance, the Housing Loan Scheme, My Home, Financing under Syarikat Perumahan Negara Berhad Funding, My First Home Scheme, Depositku, PR1MA-Rent-To-Own, Government Housing Loan Scheme, EPF Partial Withdrawal for house purchase, and Rent-to-own for People Housing Program, etc. These financing schemes assist households who are not eligible for financing to purchase a house through relaxed lending criteria by lowering interest rates for borrowing. Through the 2019 Budget, six available housing financing initiatives have been promoted, i.e., the Flexi Financial Financing Scheme (middle-income group), the Subsidy Financing Scheme (low-income group), Extension of LPPSA Financing Period, Cagamas Berhad, MyHome Fund (Crowd Funding) and Plus Discount (zero deposit). Various housing financing schemes can help the potential buyers of affordable housing to reduce their financial burdens and to ensure their housing affordability.

\subsection{Summary}

Based on the above evaluation, Figure 1 shows the ten strategies prescribed in the $D R M M$ in correlation to the key factors affecting housing affordability. Four strategies, i.e., centralising affordable housing authority, creating a unified housing database, strengthening development control, and ensuring appropriate dwelling conditions are prescribed to comprehend housing planning in Malaysia. Strengthening development control and controlling housing prices are vital to balance housing supply and demand in terms of quantity. Strategies of land preparation for affordable housing and a reduction in compliance costs and construction costs are correlated with the factor of high housing costs that influences housing affordability. The strategies of improving household financial literacy and launching various housing financing schemes can help improve home financing ability. In short, the DRMM strategies are anticipated to effectively improve housing affordability by supplying more precisely affordable housing, lowering housing costs, and improving home financing ability. However, household income and economic factors are excluded in the DRMM. In fact, they are the most critical factors as money always comes first when dealing with homeownership. As mentioned earlier, housing affordability is highly dependent on household income. To guarantee housing affordability, household income should be steadily increased, particularly in view of its relevance to housing prices. This, of course, depends on the strength of the national economy, which affects not only government's ability to deliver enough affordable housing but also the job opportunities and wage levels for households. Thus, the DRMM strategies could not guarantee housing affordability of low-income households without any consideration of these two factors. To further improve 
the anticipated effectiveness of housing affordability, due attention should be paid to the two factors in future decision-making, while the current affordable housing policies that prove to be effective should be continuously enforced, and the existing affordable housing stocks should be more efficiently utilised.

\begin{tabular}{|l|l|l|}
\hline \multicolumn{1}{|c|}{ DRMM Strategies } \\
\hline S1: Centralise affordable \\
housing authority
\end{tabular}

Figure 1. Results between the DRMM strategies and the factors affecting housing affordability.

\section{Conclusions}

In Malaysia, low-cost housing has been injected into its affordable housing policy and has evolved through the Malaysian five-year plans since its independence until 2012, when a formal housing policy was established as a National Housing Policy. Through this evolution, the government realised the necessity of managing affordable housing development more effectively and introduced the National Affordable Housing Policy in 2019. Over the decades, the government has taken different initiatives and focused on different target groups in affordable housing development. In the early period, the principle of affordable housing development was to provide low-cost housing for low-income groups. When the time passed and the demand of M40 for affordable housing increased, the government began to develop median-cost affordable housing for M40. This led to a scenario where more parties had the opportunity to be involved in affordable housing projects. Consequently, the housing development projects were changed from public sectorled to private sector-led and then were turned into joint ventures between the public and private sectors. Housing affordability has become the main concern of Malaysia's housing policy after efforts for decades, leading to the formulation of a specific housing policy to strengthen the government's initiatives in overcoming the housing affordability issue. The policy review shows that the housing affordability of low-income groups is still not guaranteed though Malaysia has long implemented affordable housing policies to improve housing affordability.

The reasons that cause low housing affordability among low-income groups are low household income, high land cost, construction cost, compliance cost, mismatch of supply and demand in terms of quantity, instability of national economy, low home financing ability, and incomprehensive housing planning due to information insufficiency. They also explain why the long-term implementation of housing policies cannot significantly guarantee Malaysian housing affordability as expected. In particular, insufficient analysis on household data that delivered inaccurate statistics to developers has caused a mismatch of housing supply and demand in terms of type of properties and location, resulting in a high vacancy rate of affordable housing and low housing affordability. The DRMM was anticipated to effectively improve the housing affordability of low-income groups in three aspects: (1) supply affordable housing more precisely by implementing the strategy of centralised affordable housing authority, creating a unified housing database, strengthening development control and ensuring appropriate dwelling condition; (2) reduce housing costs 
by preparing land for affordable housing and reducing compliance cost and construction cost; and (3) improve home financing ability by improving financial literacy and offering various housing schemes. However, the exclusion of household income and economic factors may cause the ineffectiveness of the DRMM and, as a result, housing affordability of low-income households cannot be guaranteed.

Moreover, according to international experiences [63], income mixture and sustained rehabilitation are currently two trends of affordable housing development for low-income households, both of which have a positive effect on creating job opportunities for lowincome households, so as to increase their household income and ensure their economic self-sufficiency [64-66]. Taking that into consideration, some recommendations are put forward here for the prospects of future Malaysian affordable housing development, which are divided into two perspectives, i.e., new affordable housing and abandoned or vacant affordable housing.

On the one hand, to effectively supply new affordable housing, the government should pay attention to the core problem, i.e., the mismatch of housing supply and demand in terms of housing price, type, and location. The five strategies that have been prescribed in the DRMM should be enforced to combat this situation, (1) centralise the affordable housing authority to develop more comprehensive housing planning and urban development framework; (2) create a unified housing database to produce a more accurate analysis of housing demand and supply; (3) strengthen development control to deliver adequate affordable housing and meet the market demand; (4) ensure appropriate dwelling conditions to meet household expectations; and (5) control affordable housing prices to ensure that they are within the range of household affordability. Besides the enforcement of those five strategies, international experiences such as in the U.S. [63] and in France [67] provided good lessons that new affordable housing should be encouraged along with mixed-income developments to promote social integration and to avoid a large concentration of low-income households that can lead to social problems in residential areas.

On the other hand, based on international experiences, abandoned or vacant affordable housing in Malaysia could be addressed through rehabilitation in view of their actual deficiencies. According to the Association of Valuers, Property Managers, Estate Agents and Property Consultants in the Private Sector Malaysia (PEPS), unsold housing is due to indiscriminate building by developers. Usually, the dwelling conditions such as housing size and facilities do not meet the national housing standards, consequently affecting the quality of life of residents. Unsold housing is also caused by the large concentration of lowincome groups, the poor management of building facilities, and inadequate maintenance, resulting in poor living environments [68]. Hence, to effectively rehabilitate the abandoned or vacant housing, affordable housing should be redesigned and rehabilitated in line with the market demand, and facilities and services should be strengthened, thereby ensuring a better quality of life for residents, and improving the quality of their living environment. Spirit Quarters in England is one of the successful rehabilitation schemes that transformed the vacant housing into a new residential area with 1400 housing through the improvement of community facilities, environment, employment, and education measures [69]. A case study of urban revitalization in West Philadelphia showed that a higher employment rate and a higher education level helped to increase the average household income [64]. Moreover, it is important to ensure that rehabilitation programmes are supported with enough financial supports and the building of mixed-income communities is emphasised. For instance, the EU Structural Fund was established to promote urban regeneration and social inclusion in European countries [70]. In short, rehabilitation does not merely address the issue of vacant affordable housing, but it also fosters the rise of mixed-income communities and long-term community revitalisation by improving their living environment and economic status. Although rehabilitation is neglected in the DRMM, it could be a new initiative in future policy making. 
Author Contributions: Conceptualization, J.L. and H.Y.O.; methodology, H.Y.O.; validation, J.L. and H.Y.O.; formal analysis, J.L. and H.Y.O.; resources, H.Y.O.; writing_original draft preparation, H.Y.O.; writing-review and editing, J.L. and H.Y.O.; visualization, H.Y.O.; supervision, J.L. All authors have read and agreed to the published version of the manuscript.

Funding: This research received no external funding.

Institutional Review Board Statement: Not applicable.

Informed Consent Statement: Not applicable.

Conflicts of Interest: The authors declare no conflict of interest. The funders had no role in the design of the study; in the collection, analyses, or interpretation of data; in the writing of the manuscript, or in the decision to publish the results.

\section{References}

1. Ong, T.K.; Asia Analytica. What Ails the Malaysian Residential Property Sector. Edge Mark, 6 August 2020. Available online: https:/ / www.theedgemarkets.com/article/what-ails-malaysian-residential-property-sector (accessed on 9 June 2021).

2. UN-HABITAT. Affordable Land and Housing in Asia; UN-HABITAT: Nairobi, Kenya, 2011; Volume 2, p. 26, ISBN 978-92-1-131938-5.

3. Central Bank of Malaysia. Bank Negara Annual Report 2016; Central Bank of Malaysia: Kuala Lumpur, Malaysia, 2016 ; p. 91.

4. Ismail, S. Rethinking Housing: Between State, Market and Society; Khazanah Research Institute: Kuala Lumpur, Malaysia, 2019; ISBN 978-967-16335-8-8.

5. New Straits Times. What Is Affordable Housing? New Straits Times, 5 September 2017. Available online: https://www.nst.com. my/opinion/letters/2017/09/276244/what-affordable-housing (accessed on 9 June 2021).

6. Department of Statistics Malaysia. Household Income and Basic Amenities Survey Report; Department of Statistics: Putrajaya, Malaysia, 2020; p. 14.

7. National Housing Department. National Affordable Housing Policy; National Housing Department: Putrajaya, Malaysia, 2019; pp. 1-70.

8. NAPIC. Residential Property: Trend of Overhang 2015-2019 Performance of Sold, Overhang and Launched Units, 2019; NAPIC: Putrajaya, Malaysia, 2019; pp. 1-9.

9. Shuid, S. The Housing Provision System in Malaysia. Habitat Int. 2015, 54, 1-14. [CrossRef]

10. Masram, H.; Misnan, S.H. Evolution of Policy for Affordable Housing Programmes in Malaysia. Int. J. Account. Financ. Bus. 2019, 4, 86-98.

11. Stone, M.; Burke, T.; Ralston, L. The Residual Income Approach to Housing Affordability: The Theory and the Practice; Australian Housing and Urban Research Institute: Melbourne, Australia, 2011; p. 8, ISBN 978-1-921610-71-4.

12. Luffman, J. Measuring Housing Affordability. Perspect. Labour Income 2006, 7, 16-25.

13. Mostafa, A. Rental Housing Provision Based on Affordability of the Lower End Populace: The Case of Hong Kong. Ph.D. Dissertation, The Hong Kong Polytechnic University, Hung Hom, Hong Kong, 2008.

14. Foo, C.H. The Impact of Capital Contributions and Compliance Costs on Housing Affordability. Building and Investment, August 2018, pp. 34-38. Available online: https://www.researchgate.net/publication/327011593THEIMPACTOFCAPITALCONTRIBU TIONSAND_COMPLIANCE_COSTS_ON_HOUSING_AFFORDABILITY (accessed on 8 April 2021).

15. Trimbath, S.; Montoya, J. Housing Affordability in Three Dimensions: Price, Income and Interest Rates. SSRN 2002, 1-21. [CrossRef]

16. Worthington, A.; Higgs, H. Macro Drivers of Australian Housing Affordability, 1985-2010: An Autoregressive Distributed Lag Approach. Stud. Econ. Financ. 2013, 30, 347-369. [CrossRef]

17. Stone, M.E. A Housing Affordability Standard for the UK. Hous. Stud. 2006, 21, 453-476. [CrossRef]

18. Duan, M. Investigation on Housing Affordability in Lanzhou, Northwest China. Int. J. Hous. Mark. Anal. 2011, 4, 180-190. [CrossRef]

19. Berry, M.; Hall, J. Policy Options for Stimulating Private Sector Investment in Affordable Housing across Australia-Stage 1 Report: Outlining the Need For Action; AHURi: Melbourne, Australia, 2001; pp. 30-49.

20. Kieti, R.M.; K'Akumu, O.A. Critical Factors Affecting Affordability of Mortgage Housing in Kenya. J. Hous. Built Environ. 2018, 33, 111-131. [CrossRef]

21. Nwuba, C.C.; Kalu, I.U.; Umeh, J.A. Determinants of Homeownership Affordability in Nigeria's Urban Housing Markets. Int. J. Hous. Mark. Anal. 2015, 8, 189-206. [CrossRef]

22. McCord, M.; McGreal, S.; Berry, J.; Haran, M.; Davis, P. The Implications of Mortgage Finance on Housing Market Affordability. Int. J. Hous. Mark. Anal. 2011, 4, 394-417. [CrossRef]

23. Yap, J.B.H.; Ng, X.H. Housing Affordability in Malaysia: Perception, Price Range, Influencing Factors and Policies. Int. J. Hous. Mark. Anal. 2018, 11, 476-497. [CrossRef]

24. Tan, T.H.; Samihah, H.K.; Phang, S.N. Building Affordable Housing in Urban Malaysia: Economic and Institutional Challenges to Housing Developers. Open House Int. 2017, 42, 28-35. [CrossRef] 
25. New Straits Times. PropertyGuru Hopes Gov't Considers Opening More Land for Development. New Straits Times, 29 October 2018. Available online: https://www.nst.com.my/business/2018/10/426244/propertyguru-hopes-govt-considers-opening-m ore-land-development (accessed on 14 October 2020).

26. Daily Express. Four Reasons Why M'sian Homes Are Too Expensive. Dly. Express Prop, 17 February 2020. Available online: http:/ / www.dailyexpress.com.my/interest/337/four-reasons-why-m-sian-homes-are-too-expensive/ (accessed on 20 October 2020).

27. Schuetz, J. Who's to Blame for High Housing Costs? It's More Complicated than You Think. Available online: https://www.broo kings.edu/research/whos-to-blame-for-high-housing-costs-its-more-complicated-than-you-think/ (accessed on 13 June 2021).

28. Jewkes, M.D.; Delgadillo, L.M. Weaknesses of Housing Affordability Indices Used by Practitioners. J. Financ. Couns. Plan. 2010, $21,43-52$.

29. Bramley, G. Affordability, Poverty and Housing Need: Triangulating Measures and Standards. J. Hous. Built Environ. 2012, 27, 133-151. [CrossRef]

30. Davenport, J. The Effect of Demand and Supply Factors on the Affordability of Housing. Park Place Econ. 2011, 11, 44-49.

31. Wong, J.T.Y.; Hui, E.C.M.; Seabrooke, W.; Raftery, J. A Study of the Hong Kong Property Market: Housing Price Expectations. Constr. Manag. Econ. 2005, 23, 757-765. [CrossRef]

32. Owusu-Manu, D.G.; Edwards, D.J.; Pärn, E.A.; Asiedu, R.O.; Aboagye, A. Determinants of Mortgage Price Affordability: A Study of Ghana. Int. J. Hous. Mark. Anal. 2018, 11, 734-751. [CrossRef]

33. Md Sani, N. Residual Income Measure of Housing Affordability. Int. J. Adv. Eng. Technol. 2013, 5, 1-8.

34. Mohsen, M. Affordable Housing: Need for a National Housing Network? (Second of Two Parts). Available online: https: / / www.bernama.com/en/thoughts/news.php?id=1863641 (accessed on 29 December 2020).

35. Zyed, Z.A.S.B. Assessment of Housing Affordability Problems among Younger Working Household in Greater Kuala Lumpur. Ph.D. Dissertation, University of Malaya Kuala Lumpur, Kuala Lumpur, Malaysia, 2014.

36. Sulaiman, N.; Baldry, D.; Ruddock, L. Can Low Cost Housing in Malaysia Be Considered as Affordable Housing? In Book of Abstracts: 2005 European Real Estate Society conference in association with the International Real Estate Society, Proceedings of the 12th Annual European Real Estate Society Conference; Dublin, Ireland, 15-18 June 2005; ERES: Dublin, Ireland, 2005; pp. 1-18.

37. Yusoff, N.A. Culturally Appropriate and Economically Sustainable Housing Delivery System for Malay Urban Low-Income Housheholds in Malaysia. Ph.D. Dissertation, Texas A\&M University, College Station, TX, USA, 1993.

38. Shuid, S. The Changing Role of the State and Market in Low Cost Housing Provision in Malaysia. J. Archit. Plan. Constr. Manag. 2011, 1, 39-70.

39. National Housing Department. National Housing Policy (2018-2025); National Housing Department, Ministry of Housing and Local Government: Putrajaya, Malaysia, 2018; pp. 1-144.

40. Tan, W.K. Meeting the Needs of Homeownership. In Housing the Nation: Policies, Issues and Prospects; Cagamas: Kuala Lumpur, Malaysia, 2013; pp. 3-22, ISBN 9789839931839.

41. Economic Planning Unit. The Fourth Malaysia Plan (1981-1985); Economic Planning Unit: Putrajaya, Malaysia, $1981 ;$ pp. 241-247.

42. Endan, I. Public Housing Policy in Peninsular Malaysia. Ph.D. Dissertation, Texas A\&M University, College Station, TX, USA, 1984.

43. Economic Planning Unit. Sixth Malaysia Plan; Ministry of Communications and Multimedia Malaysia: Putrajaya, Malaysia, 1991; pp. 259-261.

44. Economic Planning Unit. Seventh Malaysia Plan (1996-2000); Economic Planning Unit: Putrajaya, Malaysia, 1996 ; pp. $400-405$.

45. Department of National Housing. Towards Successful Housing Development in Malaysia. Available online: https://ehome.kpkt .gov.my/index.php/pages/view/229 (accessed on 14 June 2021).

46. Economic Planning Unit. Eighth Malaysia Plan 2001-2005; Economic Planning Unit: Putrajaya, Malaysia, 2001 ; pp. $412-415$.

47. Government of Malaysia. The Ninth Malaysia Plan 2006-2010; Economic Planning Unit: Putrajaya, Malaysia, 2006 ; pp. 437-445.

48. The Malaysian Reserve. Only 23\% of Affordable Homes Target Completed in 5 Years-The Malaysian Reserve. Malaysian Reserv, 3 November 2017. Available online: https: / / themalaysianreserve.com/2017/11/03/23-affordable-homes-target-completed-5-ye ars/ (accessed on 6 August 2021).

49. The Sun Daily. Property-One House per Household. Sun Dly, 14 October 2016. Available online: https://www.thesundaily.my /archive/401226-FTARCH401226 (accessed on 25 August 2020).

50. Economic Planning Unit. Mid-Term Review of the Eleventh Malaysia Plan, 2016-2020: New Priorities and Emphases; Ministry of Economic Affairs: Putrajaya, Malaysia, 2018; ISBN 9789675842139.

51. CSI. Prop The General Election 2018 \& the Malaysian Property Market. Available online: https://csiprop.com/the-general-electi on-2018-and-malaysias-property-market/ (accessed on 26 August 2020).

52. Cheah, S.L.; Almeida, S.J.; Ho, S.W. Affordable Housing: Challenges and the Way Forward. In Economic and Financial Developments in the Malaysian Economy in the Fourth Quarter of 2017; Central Bank of Malaysia: Kuala Lumpur, Malaysia, 2017 ; pp. 19-26.

53. PropertyGuru. The HOC (Home Ownership Campaign) 2020 - All You Need to Know! Available online: https://ww w.propertyguru.com.my/property-guides/home-ownership-campaign-hoc-2020-all-you-need-to-know-15274 (accessed on 28 August 2020).

54. Hamid, A.J. Housing: (Un)Affordability Is Key Issue. New Straits Times, 26 November 2017. Available online: https://www.nst. com.my/opinion/columnists/2017/11/307562/housingunaffordability-key-issue (accessed on 18 November 2020). 
55. Ramli, M.Z.; Malek, M.A.; Hanipah, M.H.; Lin, C.L.; Sukri, M.; Zawawi, M.H.; Abidin, Z.; Fuad, N.F.S.M. Study of Factors Influencing Construction Delays at Rural Area in Malaysia. J. Phys. 2018, 1049, 12017. [CrossRef]

56. Foo, C.H. How Rising Compliance Cost Is Impacting Housing Affordability in Malaysia. Available online: https://www.ipropert y.com.my/news/how-rising-compliance-cost-is-impacting-housing-affordability-in-malaysia/ (accessed on 14 June 2021).

57. Jabatan Penerangan Malaysia. Intipati Belanjawan 2019. Available online: http://dbook.penerangan.gov.my/dbook/dmdocume nts/intipati_belanjawan_2019/mobile/index.html\#p=8 (accessed on 14 January 2021).

58. Bilal, M.; Meera, A.K.M.; Abdul Razak, D. Issues and Challenges in Contemporary Affordable Public Housing Schemes in Malaysia: Developing an Alternative Model. Int. J. Hous. Mark. Anal. 2019, 12, 1004-1027. [CrossRef]

59. Ng, S. What Shall We Do with the Property Overhang? Available online: https://www.edgeprop.my/content/1638530/what-s hall-we-do-property-overhang (accessed on 17 February 2021).

60. Safini, S.M. Govt to Build a Million Affordable Homes in 10 Years. New Straits Times, 5 January 2019. Available online: https: / ww w.nst.com.my/news/nation/2019/01/447338/govt-build-million-affordable-homes-10-years (accessed on 15 December 2020).

61. Rameli, A.; Johar, F.; Ho, C.S. The Management of Housing Supply in Malaysia: Incorporating Market Mechanisms in Housing Planning Process. In Proceedings of the International Conference on Construction Industry 2006, Sumatera, Indonesia, 22-23 June 2006.

62. Financial Education Network. Malaysia National Strategy for Financial Literacy 2019-2023; Financial Education Network: Kuala Lumpur, Malaysia, 2019; p. 8.

63. Schwartz, A.F. Housing Policy in the United States, 3rd ed.; Routledge: New York, NY, USA, 2015; ISBN 978-0-415-83648-7.

64. Kromer, J.; Kerman, L. West Philadelphia Initiatives: A Case Study in Urban Revitalization; University of Pennsylvania: Philadelphia, Pennsylvania, 2004; p. 51.

65. Mishel, L.; Eisenbrey, R. How to Raise Wages: Policies That Work and Policies That Don't. Available online: https://www.epi.or g/publication/how-to-raise-wages-policies-that-work-and-policies-that-dont/ (accessed on 31 July 2021).

66. Lelévrier, C.; Melic, T. Impoverishment and Social Fragmentation in Housing Estates of the Paris Region, France. Urban B. Ser. 2018, 313-338. [CrossRef]

67. Liu, J. Social Housing Development amid Rapid Urbanization: Lessons and Inspirations Learnt from France. Urban Plan. Int. 2012, 27, 3-12.

68. Rahim, N.A.; Adzhar, S.M.; Basrah, N.; Majid, R.A.; Mustafar, S. Factors Lead to Overhang in Affordable Housing: A Content Analysis in Qualitative Approach. IOP Conf. Ser. Earth Environ. Sci. 2019, 385. [CrossRef]

69. Department for Communities and Local Government. Estate Regeneration National Strategy Case Studies; Department for Communities and Local Government: London, UK, 2016; p. 24.

70. Unison Open College. Housing Policies and Provision in the UK; Unison Open College: London, UK, 2003 ; pp. 1-64. 